\title{
KARAKTERISTIK NILAI DAN MORALITAS KEPEMIMPINAN PENDIDIKAN ISLAM
}

\section{CHARACTERISTICS OF VALUE AND MORALITY OF LEADERSHIP IN ISLAMIC EDUCATION}

\author{
A. Marjuni \\ Fakultas Tarbiyah dan Keguruan Universitas Islam Negeri Alauddin Makassar \\ h.marjunij@yahoo.com
}

\begin{abstract}
Abstrak
Karakteristik nilai dasar dan moralitas kepemimpinan merupakan sebuah tolok ukur yang dapat mempengaruhi perilaku manusia dalam situasi tertentu. Jika dikaitkan dengan kepemimpinan, nilai dasar berarti tolok ukur yang mendasari perilaku seorang pemimpin dalam melaksanakan kepemimpinannya. Penelitian ini dilaksanakan untuk mengetahui karakteristik dari nilai dan moralitas kepemimpinan pendidikan Islam. Penelitian ini merupakan penelitian pustaka (library research) dengan berusaha mengumpulkan informasi kepustakaan, baik melalui catatan, berbagai buku, jurnal, maupun penelitian terdahulu. Berdasarkan analisis yang dilakukan dapat diketahui bahwa karakteristik kepemimpinan harus visioner agar dapat membawa orang-orang dan organisasi menjadi lebih maju dari sebelumnya. Bahkan tidak sekedar mengalami perkembangan tetapi juga dapat mempertahankan apa yang telah diraih sampai pada beberapa generasi. Pemimpin yang efektif adalah seorang yang sangat responsif, terhadap setiap persoalan, kebutuhan, harapan dan impian dari yang dipimpinnya. Jika dikaitkan dengan moralitas kepemimpinan Islam maka perbuatan seorang pemimpin yang dianggap baik dan benar, dari sisi agama mencerminkan akhlakul karimah dan dari sisi sosial mencerminkan tindakan yang beradab. Seorang pemimpin yang bermoral pasti memiliki akhlak yang baik (akhlakul karimah) dan tindakannya merupakan tindakan beradab yang dianggap baik dan benar oleh masyarakat pada umumnya.
\end{abstract}

Kata Kunci: nilai, moralitas, kepemimpinan, pendidikan Islam

\begin{abstract}
Characteristics of basic values and leadership morality are benchmarks that can influence human behavior in certain situations. When associated with leadership, basic values mean the benchmarks that underlie the behavior of a leader in carrying out his leadership. This research was conducted to find out the characteristics of the values and morality of Islamic education leadership. This research is a library research by trying to collect library information, either through notes, various books, journals, or previous research. Based on the analysis done it can be known that the characteristics of leadership must be visionary in order to bring people and organizations to be more advanced than before. Even not only experiencing development but also being able to maintain what has been achieved through several generations. An effective leader is someone who is very responsive, to every problem, need, hope and dream of the person he leads. If it is related to the morality of Islamic leadership, the actions of a leader which are considered good and right, from a religious perspective reflect morality and from a social perspective reflect civilized actions. A moral leader must have good morals (akhlakul karimah) and his actions are civilized actions that are considered good and right by society in general.
\end{abstract}

Keywords: value, morality, leadership, Islamic education 
How to Cite: Marjuni, A. (2021). Karakteristik nilai dan moralitas kepemimpinan pendidikan Islam. Al asma: Journal of Islamic Education, 3(1), 1-14.

\section{PENDAHULUAN}

Manusia sebagai makhluk sosial selalu berinteraksi dengan lingkungannya. Agar terbentuk hubungan yang harmonis antara anggota masyarakat, maka dibutuhkan adanya seorang pemimpin yang mampu menata serta mengatur ineraksi sosial anggota masyarakat tersebut. Hal ini menandakan bahwa kepemimpinan merupakan salah satu hal yang penting, sebab tidak terlepas dengan yang namanya perencanaan, pelaksanaan, serta pengendalian dengan baik.

Kepemimpinan diartikan sebagai proses menghargai orang lain guna memahami dan menyetujui apa yang perlu dilakukan dan bagaimana menerapkannya secara efektif, serta proses memfasilitasi usaha yang dilakukan individu maupun kelompok (kolektif) untuk mencapai tujuan utama (Peramesti \& Kusmana, 2018; Yulk, 2010). Menurut Hemphill dan Coons (1957) kepemimpinan didefinisikan sebagai perilaku individu yang mengarahkan aktivitas kelompok untuk mencapai sasaran atau tujuan bersama. Menurut Noor (2013) kepemimpinan merupakan suatu proses mempengaruhi dan mendukung orang lain untuk bekerja lebih antusias menuju tercapainya tujuan. Kemudian Ivancevich (2008) menjelaskan bahwa leadership as a process of influencing other to facilitate the attainment of ornanitationally relevant goal.

Djihadah (2020) mengungkapkan bahwa kepemimpinan merupakan kemampuan untuk memengaruhi, menggerakkan, dan mengarahkan tindakan seseorang atau sekelompok orang untuk mencapai tujuan tertentu dalam situasi tertentu. Hal yang sama juga dijelaskan oleh House (1976) bahwa kepemimpinan adalah kemampuan yang dimiliki individu untuk mempengaruhi, memotivasi, dan membuat orang lain mampu memberikan kontribusinya untuk efektivitas dan keberhasilan sekolah. Berdasarkan beberapa definisi di atas terlihat jelas bahwa seorang pemimpin hendaknya memiliki kemampuan untuk menggerakkan, memerintah, membimbing, serta melarang anggotanya dengan maksud agar anggotanya tersebut mau bererja sama guna mencapai tujuan tertentu secara efektif dan efisien.

Dalam perspektif Islam, konsep kepemimpinan sering disebut sebagai khalifah yang mengandung arti wakil. Akan tetapi, kata khalifah kemudian mengalami pergeseran dengan masuknya kata amir yang berarti penguasa (Maimunah, 2017). Menurut Mangkunegara dalam Anam (2017) kepemimpinan Islam dapat didefinisikan sebagai hubungan antara individu atau bawahan dengan atasannya yang mempengaruhi orang lain sehingga mereka memiliki keinginan untuk bekerja guna mencapai tujuan tertentu dengan berpedoman pada norma-norma yang sesuai dengan Al-Qur'an dan hadis. Qamar dalam Burhanuddin (2019) mengungkapkan bahwa konsep kepemimpinan dalam Islam dianggap sebagai hal yang begitu penting sebagaimana Rasulullah saw., bersabda: Dari Abu Said dari Abu Hurairah bahwa keduanya berkata, Rasulullah saw., berdabda, "Apabila ada tiga orang keluar bepergian, hendaklah mereka menjadikan salah satu sebagai pemimpin" (Hadits riwayat Abu Daud).

Pemimpin dalam lembaga pendidikan Islam, memiliki tanggung jawab yang lebih dari pada pemimpin pendidikan lainnya. Hal ini dikarenakan seorang pemimpin 
pendidikan Islam harus melaksanakan kepemimpinannya secara Islami pula. Baik sifat, perilaku dan tindakan yang dilakukan harus mencerminkan ajaran agama Islam. Bahkan ia juga harus memiliki budi pekerti yang baik dan benar (Usman, 2014). Hal yang sama juga diungkapkan oleh Syam (2017) bahwa kepemimpinan dari seorang pemimpin sebagai individu yang bertanggung jawab pada lembaga pendidikan Islam memiliki kewajiban untuk bekerja lebih keras agar seluruh potensi yang ada di lembaga tersebut dapat dimafaatkan secara maksimal demi mencapai tujuan yang diinginkan. Seorang pemimpin pendidikan harus berpegang pada prinsip kepemimpinan pendidikan Islam yaitu AlQur'an dan hadits, serta memiliki jiwa kepemimpinan dalam pengembangan sumber daya manusia di lembaga pendidikan (Wahab, 2020). Sementara itu, Khumaini dan Wiranata (2019) memperjelas bahwa kepemimpinan dalam konteks pendidikan Islam memiliki peran yang sangatlah penting sebab seorang pemimpin harus mampu mengarahkan, membimbing, dan menggerakkan demi terwujudnya visi dan misi pendidikan Islam, yaitu mewujudkan kholifah fil ardyang yang bertakwa.

Seorang pemimpin (pemuka) pendidikan Islam sepatutnya mengetahui dan mengerti berbagai nilai yang mendasari kepemimpinan pendidikan Islam. Hal ini penting diketahui oleh seorang pemimpin untuk mengukur seberapa pantas ia menjadi seorang pemimpin. Dari sini, diharapkan ia dapat memperbaiki dan meningkatkan kualitas kepemimpinannya. Syadzili (2018) menjelaskan bahwa terdapat dua pandangan pendidikan Islam, yaitu: pertama, pendidikan Islam sebagai kegiatan pendidikan yang dirancang untuk mewuudkan nilai-nilai Islam. Kedua, pendidikan Islam sebagai sistem pendidikan yang dikembangkan dan didorong oleh ajaran dan nilai-nilai Islam. Kedua pandangan tersebut menunjukkan bahwa setiap pemimpin yang berperan sebagai pemimpin dalam pendidikan Islam harus selalu menanamkan ajaran dan nilai-nilai Islam.

Terlepas dari hal tersebut, seorang pemimpin juga harus memiliki perilaku yang mencerminkan bahwa ia merupakan pemimpin yang bermoral. Menurut Rusnadi \& Hafidhah (2019) moral yang harus dimiliki oleh para pemimpin pendidikan Islam adalah menjunjung nilai-nilai luhur Iman, Islam, dan Ihsan agar dapat menjalankan kepemimpinan pendidikan Islam sesuai dengan hukum Islam. Selain itu, Pertiwi, Cahyani, Diana, dan Gunawan (2017) menjelaskan bahwa perilaku yang baik dan benar dari seorang pemimpin dipengaruhi oleh nilai dan etika yang diterapkannya. Lebih lanjut oleh Pertiwi, Cahyani, Diana, dan Gunawan (2017) bahwa nilai-nilai moral mencakup tingkah laku, sikap dan nilai kehidupan baik atau buruknya diakui oleh orang lain dengan tidak memandang agama, budaya, rasa tau suku, bangsa.

Moralitas seorang pemimpin menjadi perhatian dan bahan perimbangan bagi orang lain untuk melakukan penilaian. Setiap orang menginginkan pemimpin dengan akhlak yang baik sehingga dapat dijadikan acuan atau teladan. Sekalipun jika kita melihat kenyataan yang ada masih terdapat banyak masalah terkait moralitas pemimpin yang buruk (Susanti, 2019). Berdasarkan pemaparan di atas, penelitian ini laksanakan dengan tujuan untuk mengetahui bagaimana kriteria atau karaktetistik dari nilai kepemimpinan dan karakterisktik moralitas kepemimpinan dalam pendidikan Islam. Pemimpin dapat dikatakan sebagai sosok ideal yang layak untuk menjadi seorang pemimpin, jika seorang pemimpin sudah memahami dan menerapkan nilai dasar kepemimpinan dan moral yang insya Allah akan tercapai sebuah keberhasilan dalam kepemimpinannya. 
Pemimpin yang dikatakan berhasil ialah seseorang yang begitu peka, yaitu senantiasa tanggap akan setiap permasalahan, pengharapan, kebutuhan, serta impian dari pihak-pihak yang dipimpinnya. Agar menjadi seorang pemuka (pemimpin) yang responsif maka harus menjadi pendengar dalam tiap keluhan, impian, harapan, serta kebutuhan bawahannya. Selain itu juga harus selalu aktif untuk mencari penyelesaian setiap persoalan atau tantangan yang menjadi ujian organisasinya. Pemuka yang berhasil merupakan seorang yang bisa melatih atau mendampingi, dalam hal ini pendamping bagi mereka yang dipimpinnya (performance coach) (Rivai, Bachtiar, \& Amar, 2014). Seorang pemimpin pada dasarnya merupakan pemimpian moral sebab segala sikap, cara berpkiri, serta perilakunya akan menjadi panutan bagi orang lain. Bayangkan jika sikap, ucapan, dan perilaku seorang pemimpin tidak baik, tidak bermoral, maka semua orang akan jatuh ke dalam kekacauan dan organisasi tentau saja akan hancur.

\section{METODE PENELITIAN}

Metode yang diterapkan dalam penelitian ini adalah penelitian pustaka (library research) yang menggunakan pendekatan dari penelitian kualitatif. Pada kegiatan ini, penulis berusaha mengumpulkan berbagai informasi kepustakaan baik melalui catatan, berbagai buku, ataupun artikel dan penelitian terdahulu. Kumpulan informasi yang dinamakan data lalu dianalisis agar didapatkan karakteristik nilai dan moralitas kepemimpinan pendidikan Islam.

\section{HASIL DAN PEMBAHASAN}

\section{Pengertian Nilai Kepemimpinan Pendidikan Islam}

Nilai menurut Bahasa ialah kadar, mutu, dan beberapa hal penting atau berguna bagi kemanusiaan (Qodratillah, 2011). Sementara secara istilah, nilai berarti indikator untuk memilih atau menghukum perilaku dan target tertentu (Rosyadi, 2004). Definisi nilai secara istilah sebenarnya sangat beragam, beberapa ahli ada yang memaparkan opini mereka tentang definisi nilai. Dan tentu saja masing-masing ahli memiliki pendapat yang berbeda sesuai dengan konteks dan cara pandang mereka masing-masing.

Danandjaja sebagaimana dikutip Nurul Hidayah mengungkapkan bahwa ada 3 hal yang harus dipaparkan mengenai nilai. Pertama, definisi bahwa nilai itu mempunyai dampak pada sikap atau budi pekerti seseorang. Kedua, defenisi terkait adanya tata tingkat preferensi nilai pada modus tingkah laku tertentu atau kondisi akhir tertentu. Ketiga terkait sesuatu apa yang benar-benar disebabkan oleh nilai (Hidayah, 2016).

Menurut Hoffmeister yang dikutip Rosyadi, nilai ialah implikasi hubungan (kaitan) yang dilakukan manusia yang sedang penilaian antara suatu benda dengan satu ukuran (Rosyadi, 2004). Menurut Gordon Alport sebagaimana dikutip oleh Mulyana, nilai ialah keyakinan yang mempengaruhi seseorang untuk bertindak sesuai dengan pilihannya. Sedangkan menurut Fraenkel yang dikutip oleh Nur Efendi, nilai bisa dibataskan sebagai ide/gagasan ataupun konsep tentang suatu hal yang dianggap perlu dalam kehidupan seseorang (Efendi, 2015).

Tetapi perlu digarisbawahi bahwa nilai ialah kualitas empiris yang seolah tidak dapat dibatasi. Akan tetapi seperti yang dikemukakan Louis Katsoff yang dikutip oleh Nur 
Efendi, pada kenyataannya bahwa meski nilai tidak terdefinisi bukan berarti tidak bisa dipahami (Efendi, 2015).

Dari beberapa pandangan dari para ahli yang diuraikan di atas, bisa diputuskan bahwa nilai merupakan sebuah tolok ukur yang dapat mempengaruhi perilaku manusia dalam situasi tertentu. Jika dikaitkan dengan kepemimpinan, nilai dasar berarti tolok ukur yang mendasari perilaku seorang pemimpin dalam melaksanakan kepemimpinannya.

Biasanya nilai dasar kepemimpinan menggambarkan beberapa sifat yang berkualitas dari pemimpin. Pada ajaran Islam, beberapa sifat dari seorang pemimpin merujuk pada sifat-sifat yang diajarkan oleh Rasulullah saw. Jadi, yang dimaksud dengan nilai dasar kepemimpinan Pendidikan islam ialah tolak ukur yang mendasari perilaku seorang pemimpin dalam melaksanakan kepemimpinan secara Islami.

Ada beberapa karakteristik nilai dasar dalam kepemimpinan pendidikan islam yang penting diperhatikan seorang pemimpin. Hal ini dimaksudkan untuk membentuk sosok seorang pemimpin yang ideal sehingga ia akan sukses dalam melaksanakan kepemimpinannya. Nilai dasar kepemimpinan pendidikan Islam dapat merujuk pada beberapa sifat yang sudah dianjurkan oleh Nabi Muhammad saw. beberapa diantaranya ialah kejujuran (shiddiq), tanggung jawab (amanah), komunikatif (tabligh), cerdas (fathonah), berperilaku dan berpikir positif (husnudzan), memperbanyak silaturrahim, disiplin akan waktu dan memenuhi janji, berperilaku yang efektif dan efisien, memberi upah dengan tepat dan cepat (Efendi, 2015).

Sementara itu, Rivai, Bachtiar, dan Amar menjabarkan nilai dasar kepemimpinan menjadi lebih kompleks. Menurut mereka, nilai islam dalam kepemimpinan yang efektif dapat didapatkan dalam Al-Qur'an ataupun hadits, baik tersurat ataupun yang tersirat. Beberapa nilai yang dimaksud antara lain cerdas, visioner, inisiatif, ikhlas untuk berkorban, tanggung jawab, optimis, responsif, sederhana, inovatif, toleran, empati, efektif dan efisien, keteladanan, dan terbuka (Rivai, Bachtiar, \& Amar, 2014).

Nilai-nilai yang mengacu pada perilaku Rasulullah saw. maupun nilai yang terdapat pada Al-Qur'an serta hadits sebenarnya berada pada satu kesatuan, yaitu ajaran agama Islam. Meskipun pada saat itu, belum dikenal istilah-istilah yang modern seperti visioner, responsif, inisiatif, inovatif, dll seperti pada saat ini. Namun pada hakikatnya, semua nilai itu sudah ada dalam ajaran agama Islam sejak dulu dan akan tetap ada selamanya. Oleh sebab itu, dapat disimpulkan bahwa nilai dasar kepemimpinan, terutama kepemimpinan pendidikan Islam dapat berpijak dalam wahyu agama Islam, baik tercantum pada Al-Qur'an dan hadits, serta meneladani perilaku Rasulullah saw. nilai dasar tersebut antara lain:

a. Cerdas (fathonah)

Fathonah (mampu) termasuk suatu pondasi atau nilai di mana dalam Islam sifat ini menempati posisi yang begitu penting karena pentingnya secara fundamental memuat segala ranah dalam kehidupan manusia (Rivai, Bachtiar, \& Amar, 2014).

Kecerdasan menjadi kunci untuk meraih kesuksesan. Dengan memiliki kecerdasan, manusia dapat mengatasi berbagai permasalahan yang dihadapi. Ia dapat mengambil langkah dengan tepat sehingga akan memudahkannya untuk meraih kesuksesan yang diinginkan.

Hal tersebut bersesuaian dengan firman Allah swt. berikut ini:

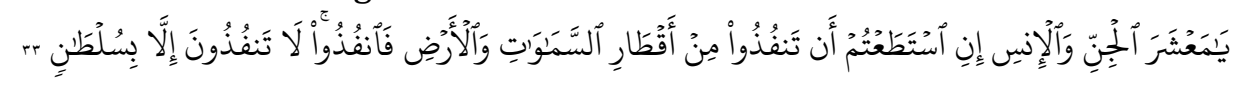


Artinya: Hai jama'ah jin dan manusia, jika kamu sanggup menembus (melintasi) penjuru langit dan bumi, maka lintasilah, kamu tidak dapat menembusnya kecuali dengan kekuatan. (QS. Ar-Rahman [55]: 33)

Secara umum kecerdasan diklasifikasikan menjadi tiga jenis, yakni tingkatan kecerdasan intelektual (IQ), kecerdasan emosianal (EQ), serta kecerdasan spiritual (SQ). Seseorang yang menjadi pemimpin tidak bisa mengandalkan salah satu dari kecerdasan tersebut, tetapi harus memiliki ketiga-tiganya.

Sementara menurut Mac Gilchrist yang dikutip oleh Husaini Usman, terdapat 9 kecerdasan dalam kepemimpinan Pendidikan, yakni:

1) Kecerdasan secara etika, meliputi: menghormati sesama, mengutamakan kebenaran, adil serta bertanggung jawab.

2) Kecerdasan secara spiritual, meliputi: berakhlak mulia(iman dan taqwa), mencari makna hidup.

3) Kecerdasan secara kontekstual, meliputi: mengetahui lingkungan baik global, nasional, regional ataupun local.

4) Kecerdasan secara operasional, meliputi: meningkatkan perencanaan, mengatur manajemen, mendistibusikan kepemimpinan serta berpikir strategis.

5) Kecerdasan secara emosional, meliputi: mengenali diri sendiri, dapat membenamkan emosi, meningkatkan kepribadian dan mengenal diri orang lain.

6) Kecerdasan secara kolegial, meliputi: keinginan tehadap mencapai target bersama, membangun kepercayaan, pembelajaran secara bertingkat dan mengetahui kreasi.

7) Kecerdasan secara reflektif, meliputi: evaluasi diri, mempelajari secara mendalam, menyediakan waktu untuk refleksi, dan menerima kritik untuk penyempurnaan.

8) Kecerdasan secara pedagogik, meliputi: memajukan visi serta tujuan pembelajaran baru, tindakan keterbukaan kelas, berperilaku mendidik dan meningkatkan kompetensi mengajar.

9) Kecerdasan secara sistematik, meliputi: pemberian contoh bentuk mental, mengatur diri sendiri, mengefektifkan jaringan kerja, dan berpikir sistem (Usman, 2014).

Idealnya seorang pemimpin harus kompleks memiliki sembilan kecerdasan tersebut. Namun, harus diketahui bahwa orang-orang tertentu saja yang bisa memilikinya. Karena setiap orang pasti memiliki kelebihan dan kelemahan masingmasing. Setidaknya seorang pemimpin haruslah mempunyai tiga macam tipe kecerdasan, yakni intelektual, emosional, serta spiritual. Dengan memiliki tiga kecerdasan tersebut seorang pemimpin sudah mempunyai bekal dasar untuk menjalankan kepemimpinan. Meskipun demikian, seorang pemimpin harus tetap berusaha untuk terus mengasah kecerdasan yang lainnya agar ia dapat melaksanakan peran dan tugas kepemimpinannya secara maksimal.

b. Jujur (shidiq)

Sifat jujur menjadi salah satu pondasi yang paling urgen ketika membentuk seorang pemimpin yang baik (Efendi, 2015). Dengan kejujuran, semua yang sedang dilakukan akan berlangsung lancer dan tidak merugikan pihak yang lain, sebab tidak terdapat unsur bohong di dalamnya. Sifat jujur ini merupakan salah satu sifat wajib dari Rasulullah saw. yang harus diteladani. 
c. Visioner

Visioner ialah orang yang mempunyai pandangan ataupun wawasan ke masa depan (Qodratillah, 2011). Menurut Veithzal Rivai dan Arviyan Arifin yang dikutip oleh Nurul Hidayah, Visionary Leadership adalah pemuka yang mempunyai arah serta wujud masa depan jelas yang merupakan rancangan masa depan yang tersepakati dengan perasaan kebersamaan dan komitmen kuat untuk mewujudkannya (Hidayah, 2016).

Pemimpin yang ideal sangan perlu mempunyai visi dan memperlihatkan komitmennya sebagaimana dalam Islam yang menuntut agar pengikutnya harus beriman kepada Allah swt. agar ia bisa sampai pada apa yang dicita-citakan, sebagaimana firman Allah dalam surah Al-Bayyinah ayat 5.

d. Inisiatif

Inisiatif ialah suatu prinsip yang juga perlu dimiliki oleh seorang pemimpin. Setiap pemimpin harus mempunyai inisiatif agar dapat mengambil langkah tanpa harus diberi tahu supaya dapat mengembangkan organisasi yang dipimpinnya menjadi lebih bermutu.

Hal ini pun bersesuaian dengan firman Allah swt. berikut ini:

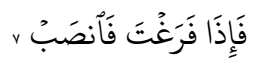

Artinya: Maka apabila kamu telah selesai dari (sesuatu urusan), kerjakanlah dengan sungguh-sungguh (urusan) yang lain. (QS. Al-Insyirah: 7).

Firman Allah di atas mengisyaratkan tentang prinsip inisiatif, seseorang yang menjadi pemimpin tidak boleh terperdaya hanya di dalam satu rutinitas yang menyita hampir seluruh waktu tugasnya. Pemimpin perlu memunculkan inisiatifnya di dalam memotivasi dan meningkatkan organisasi yang ia pimpin agar bisa bersaing dan berkompetisi dengan organisasi lain di lingkungan kompetitifnya (Rivai, Bachtiar, \& Amar, 2014).

e. Ikhlas berkorban

Seorang pemimpin seharusnya mengedepankan sikap rela berkorban. Pemimpin yang mempunyai sifat ini akan selalu bisa memberikan harapan kepada lingkungannya bahwa ia beserta lingkungannya tetap bisa menjalankan kewajibannya dan memenuhi seluruh haknya, baik bawahan maupun pihak yang dilayani (Rivai, Bachtiar, \& Amar, 2014). Jika dalam lingkungan pendidikan, berarti seorang pemimpin seharusnya memenuhi hak-hak guru, staff, karyawann, serta hak para siswanya.

f. Bertanggung jawab (amanah)

Sifat bertanggung jawab harus dimiliki oleh setiap pemimpin, sebagaimana hadits Rasulullah saw.

Artinya: Telah menceritakan kepada kamu Ismail. Telah menceritakan kepadaku Malik dari Abdullah bin Dinar dari Abdullah bin Umar r.a, Rasulullah saw. bersabda: "Ketahuilah setiap kalian adalah pemimpin, dan setiap pemimpin akan dimintai pertanggungjawaban atas yang dipimpinnya" (HR. Bukhary No. 6605).

Seorang pemimpin wajib bertanggung jawab terhadap seluruh pihak yang terkait, misalnya bawahan, masyarakat, pemerintah, dan yang terpenting ialah 
bertanggung jawab kepada Allah swt. sebagai Tuhan pencipta alam semesta (Rivai, Bachtiar, \& Amar, 2014).

g. Percaya diri

Seseorang yang menjadi pemimpin harus senantiasa untuk yakin dengan kemampuan yang ia miliki dan setiap bebannya akan bisa diwujudkan (Shulhan, 2004). Rasa percaya diri seorang pemimpin sangat diperlukan dalam merealisasikan visi dan misi organisasinya. Bahkan di dalam Al-Qur'an pun disebutkan:

$$
\text { 10. }
$$

Artinya: Kemudian apabila kamu telah membulatkan tekad, maka bertawakallah kepada Allah. Sesungguhnya Allah menyukai orang-orang yang bertawakal kepadanya. (QS. Ali-Imran: 159).

Meskipun seorang pemimpin memiliki rasa percaya diri bahwa ia dapat merealisasikan visi misinya, namun harus diingat bahwa segala sesuatunya yang menentukan adalah Allah swt. Oleh sebab itu seorang pemimpin haruslah punya usaha semaksimal mungkin dan senantiasa bertawakal kepada-Nya.

h. Berpikir positif (husnuzhan) bersikap positif

Berpikir positif dan bersikap positif ini berkaitan dengan rasa percaya diri. Pemimpin yang berpikiran positif akan memotivasinya agar bersikap positif pula. Oleh sebab itu pada setiap tindakan akan dilakukannya dengan penuh optimisme dan senantiasa bertawakal kepada Allah swt.

i. Responsif

Responsif berkaitan dengan kemampuan seorang pemimpin dalam mengetahui dan memahami kebutuhan orang-orang yang ada di sekitarnya, jika dalam lingkungan pendidikan termasuk guru, staf, karyawan, siswa, serta masyarakat. Seorang pemimpin yang responsif juga akan senantiasa berusaha untuk mewujudkan kebutuhan mereka. Sikap responsif disinggung di dalam kalam Allah pada surah AlHujurat ayat 13 (Rivai, Bachtiar, \& Amar, 2014).

j. Empati

Empati ialah perilaku dan kepiawaian seseorang untuk mengerti dan merasakan apa yang sedang dialami orang lain. Seorang pemimpin yang mempunyai sifat ini akan senantiasa akrab dengan masyarakatnya, baik itu bawahan hingga yang dilayani (Rivai, Bachtiar, \& Amar, 2014). Ia juga akan senantiasa bersikap lembut dan menghargai orang-orang yang disekitarnya, sebagaimana firman Allah swt. berikut:

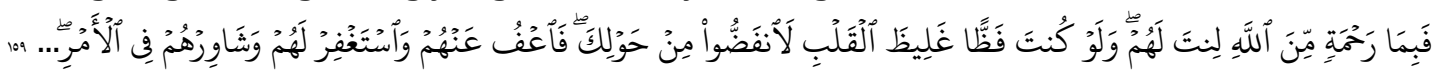

Artinya: Maka disebabkan rahmat dari Allah-lah kamu berlaku lemah lembut terhadap mereka. Sekiranya kamu bersikap keras lagi berhati kasar, tentulah mereka menjauhkan diri dari sekelilingmu. Karena itu maafkanlah mereka, mohonkanlah ampun bagi mereka, dan bermusyawaratlah dengan mereka dalam urusan itu (QS. AliImran: 159).

k. Inovatif

Inovatif yang disebut juga inovasi senantiasa berjalan beriringan dengan kreativitas. Agar bisa mencapai tingkatan ini, seseorang itu haruslah cerdas, khususnya dalam aspek intelektual (Rivai, Bachtiar, \& Amar, 2014). Seorang pemimpin 
yang inovatif mampu membuat program-program yang dapat meningkatkan kualitas oraganisasi yang dipimpinnya.

l. Toleran

Sifat toleran dapat membantu mewujudkan hubungan kerja yang harmonis. Karena dengan begitu, tidak akan terjadi perpecahan yang dapat merongrong kekompakan dalam melaksanakan visi-misi yang sudah ditetapkan. Hal ini pun sudah dijelaskan di dalam Al-Qur'an surah Al-Hujurat sebagai berikut:

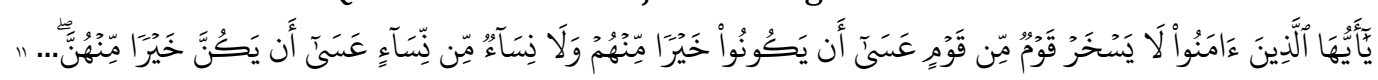

Artinya: Hai orang-orang yang beriman, janganlah sekumpulan orang laki-laki merendahkan kumpulan yang lain, boleh jadi yang ditertawakan itu lebih baik dari mereka.

m. Keteladanan

Hampir di setiap organisasi, seorang pemimpin senantiasa dijadikan figur. Hal ini tidaklah berlebihan, karena corak budaya kita sifatnya paternalistik, bukan hanya itu seorang pemimpin pun dianggap sebagai sosok yang mempunyai beberapa kelebihan jika dibandingkan dengan rakyat biasa (Rivai, Bachtiar, \& Amar, 2014). Karena itu, pemimpin sudah sepatutnya mampu menjadi sosok yang dapat diteladani oleh bawahannya, sebagaimana dulu Rasulullah saw. menjadi seorang pemimpin agama dan negara yang dapat menjadi panutan bagi seluruh umat Islam.

n. Disiplin

Sosok pemimpin perlu usaha yang sungguh-sungguh di dalam menegakkan kedisiplinan saat bekerja, kedisiplinan waktu, serta dalam menaati seluruh peraturan yang sudah ditetapkan pada organisasi/Lembaga yang ia pimpin (Shulhan, 2004). Sikap disiplin bersesuaian dengan kalam Allah pada surah Huud ayat 112.

o. Terbuka (transparan) dan komunikatif (tabligh)

Diantara ciri profesional ialah sikap komunikatif dan transparannya (Efendi, 2015). Kedua sikap tersebut saling berkaitan karena pemimpin yang bersikap terbuka (transparan) akan mengkomunikasikan apa yang berkaitan dengan organisasinya kepada bawahan maupun masyarakat. Sikap tersebut bersesuaian dengan firman Allah swt. dalam surat Adh-Dhuhaa: 11 dan surat Al-Maidah: 67. Selain itu, pemimpin yang komunikatif juga memiliki kecakapan dalam berbicara, biasanya apa yang ia sampaikan akan lebih mudah dipahami oleh orang lain, jadi apa yang disampaikan bisa diterima dengan respon yang baik.

\section{Hakikat Moralitas Kepemimpinan Pendidikan Islam}

Istilah moralitas berasal dari kata mores yang diartikan aturan kesusilaan (Rivai, Bachtiar, \& Amar, 2014). Kata mores ialah bentuk jaman dari mos yang memiliki arti kebiasaan atau adat. Secara etimologis, moral memiliki kesamaan arti dengan kata etika, yaitu kebiasaan atau adat. Hanya saja moral berasal dari Bahasa latin sementara etika berasal dari bahasa Yunani. Dengan artian lain, arti kata moral sama saja dengan kata etika, karenanya rumusan arti kata moral ialai berbagai nilai dan norma yang menjadi pegangan bagi suatu individu atau kelompok dalam mengatur perilakunya (Efendi, 2015).

Seseorang yang bermoral maka ia akan memiliki perilaku yang baik dalam kehidupannya. Karena moral itu sendiri memang mengarah pada perilaku yang baik. 
Sebagaimana pendapat Sumaryono yang dikutip oleh Veitzhal Rivai dkk. yang menyatakan bahwa moral ialah aturan kesusilaan yang memuat segala norma untuk perlakuan, perbuatan, dan moral yang baik (Rivai, Bachtiar, \& Amar, 2014). Jadi, seseorang yang bermoral akan senantiasa berpegang teguh dengan berbagai nilai serta norma yang telah diyakininya sehingga ia akan berperilaku baik, dan tidak akan melakukan perilaku yang buruk. Moral digolongkan menjadi 2 macam, yakni:

a. Moral murni, adalah moral yang ada dalam setip manusia manusia, untuk pengejewantahan dari pancaran Ilahi. Moral murni disebut sebaagai hati nurani.

b. Moral terapan, yaitu karakter yang didapat dari berbagai ajaran, seperti agama dan adat (Rivai, Bachtiar, \& Amar, 2014).

Moral termasuk pengetahuan yang ada sangkutpautnya dengan budi pekerti manusia beradab. Moral pun berarti ajaran baik. Sementara untuk moralitas lebih mengarah pada kualitas dalam perbulan manusia, sehingga perilaku itu disebut baik ataupun benar (Rivai, Bachtiar, \& Amar, 2014). Jadi, dalam hal ini terdapat perbedaan antara moral dan moralitas. Moral masih berupa konsep sementara moralitas berupa praktik atau aplikasi dari konsep tersebut. Moralitas merupakan perilaku nyata sebagai bentuk perwujudan dari moral.

Moralitas kepemimpinan pendidikan Islam merupakan perbuatan dari seorang pemimpin yang tidak menyimpang dari ajaran agama maupun ajaran-ajaran yang berkembang di masyarakat. Jadi dalam hal ini, moralitas kepemimpinan pendidikan Islam berorientasi pada dunia dan akhirat sekaligus. Tidak hanya berorientasi pada dunia saja atau akhirat saja.

Ada beberapa kriteria terkait moralitas kepemimpinan pendidikan Islam, di antaranya yaitu:

a. Hati yang melayani

Kepemimpian yang memberikan pelayanan sesungguhnya berasal dari diri seorang pemimpin itu sendiri, yaitu hati. Setiap pemimpin seharusnya memiliki hati yang siap melayani. Bukan sekedar ucapan semata tetapi juga harus benar-benar tertanam di lubuk hatinya. Karena kepemimpinan yang dari hati itulah yang kemudian akan melahirkan sebuah karakter kepemimpinan sejati yang siap untuk melayani.

Menurut Ben Blanchard yang dikutip oleh Rivai dkk. ada beberapa karakteristik dan nilai yang terlihat dari jiwa pemimpin yang mempunyai hati melayani. Pertama, sasaran paling utama dari pemimpin ialah melayani kepentingan masyarakatnya. Orientasinya ialah bukan pada kepentingan pribadi ataupun golongannya, tetapi lebih kepada kepentingan seluruh pihak yang dipimpinnya. Kedua, mempunyai kerinduan untuk senantiasa membangun dan meningkatkan pihak-pihak dibawahnya. Ketiga, mempunyai perhatian dan rasa kasih kepada mereka yang ia pimpin. Rasa kasih ini terwujud dalam bentuk kepedulian akan kepentingan, kebutuhan, harapan, serta impian dari masyarakatnya. Keempat, akuntibilitas berarti bisa diandalkan dan sangat bertanggung jawab. Artinya semua perkataan hingga perilakunya bisa dipercayai (Rivai, Bachtiar, \& Amar, 2014).

Apabila seseorang pemimpin memiliki ciri-ciri sebagaimana disebutkan di atas, maka Insya Allah hatinya telah siap untuk menjadi seorang pemimpin. Jika hatinya siap melayani maka tindakan yang dilakukan juga akan mencerminkan karakter seorang pemimpin yang siap melayani pula. Ia akan memimpin dengan penuh 
keikhlasan serta rela berkorban untuk melakukan yang terbaik demi mereka yang dipimpinnya. Selain itu, ia juga lebih mengutamakan kepentingan publik daripada kepentingan pribadinya.

b. Kepala yang melayani

Menjadi sosok pemimpin tidaklah mudah untuk dilakukan. Karena selain memimpin dirinya sendiri ia juga harus memimpin orang lain, yang masing-masing orang memiliki karakter yang tidak sama satu sama lain. Keinginan serta kebutuhan mereka juga tentu saja tidak sama. Sehingga dalam hal ini seorang pemimpin sangat perlu menjadi kepala yang melayani.

Sebagai kepala yang melayani, maka seorang harus memiliki serangkaian metode kepemimpinan supaya kepemimpinannya berjalan secara efektif. Ia tidaklah cukup jika hanya mengandalkan hati yang melayani saja, namun juga perlu ditunjang dengan kemampuan untuk mengelola kepemimpinannya.

Terdapat dua aspek yang membahas tentang visi, yakni visionary role dan implementation role. Ini artinya sosok yang menjadi pemimpin bukan hanya bisa membangun ataukah membuat visi untuk organisasinya, namun juga mempunyai skill untuk menerapkan visi it uke dalam suatu rangkaian perilaku atau kegiatan yang dibutuhkan untuk memenuhi target visi itu (Rivai, Bachtiar, \& Amar, 2014).

Berkaitan dengan hal di atas, maka seorang pemimpin harus melatih anak buahnya untuk mandiri dalam berbagai hal. Sehingga mereka memiliki inisiatif sendiri dalam menghadapi berbagai situasi, tidak sepenuhnya menunggu perintah dari pemimpinnya. Karena mereka bukanlah robot yang harus selalu menunggu perintah. Jadi, diantara pemimpin dan pihak yang dipimpin haruslah sama-sama bergerak untuk mencapai tujuan yang diharapkan.

c. Tangan yang melayani

Sebagai seorang pemimpin ia bukan sekedar memiliki hati yang melayani ataupun menjadi seorang kepala yang melayani. Tetapi juga harus memiliki tangan yang melayani pula. Artinya, selain memiliki karakter dan kemampuan dalam hal kepemimpinan, ia juga perlu memperlihatkan perilaku atau kebiasaan seorang pemimpin. Sosok ini harus mampu memposisikan dirinya sesuai dengan tugas yang diembannya.

Menurut Ken Blanchard yang dikutip oleh Veitzhal Rivai, dkk. ada tiga kebiasaan seorang pemimpin yakni:

1) Pemimpin bukan sekedar memuaskan siapa yang dipimpinnya, akan tetapi mempunyai kerinduan untuk memuaskan Tuhan. Dengan artian, dia hidup sejalan dengan firman Tuhan. Ia mempunyai misi untuk senantiasa memuliakan Tuhan setiap apa yang ia pikirkan, perbuat dan dikatakan.

2) Pemimpin sejati fokus terhadap hal spiritual dibanding hal kesuksesan duniawi. Apa saja yang ia lakukan bukan untuk mencapai penghargaan, melainkan agar dapat melayani sesamanya. Ia lebih mengedepankan relasi yang penuh kasih dibandingkan kekuasaan semata dan status.

3) Pemimpin sejati senantiasa mau belajar dan bertumbuh dalam segala aspek, baik pengetahuan, keuangan, relasi kesehatan, dan lain hal. Setiap hari senantiasa menselaraskan (recalibrating) dirinya pada komitmen untuk melayani Tuhan dan 
sesama. Melalui solitude (keheningan), scripture (membaca firman Tuhan), dan prayer (doa) (Rivai, Bachtiar, \& Amar, 2014).

Menjadi seorang pemimpin bukan berarti ia bisa melakukan segala sesuatu atas kehendaknya sendiri. Karena hakikat memimpin bukan semata-mata menuruti kemauan egonya yang tidak pernah ada habisnya. Melainkan mampu mengayomi orang-orang yang dipimpinnya dengan sebaik-baiknya. Islam pun melarang apabila seorang pemimpin menyelewengkan kekuasaannya untuk hal yang tidak benar.

Sebagaimana firman Allah swt. berikut ini:

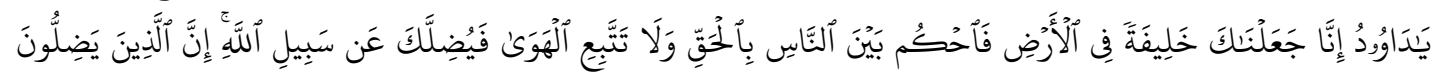

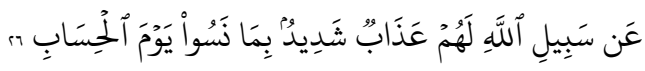

Artinya: Hai Daud, sesungguhnya Kami menjadikan kamu khalifah (penguasa) di muka bumi, maka berilah keputusan (perkara) di antara manusia dengan adil dan janganlah kamu mengikuti hawa nafsu, karena ia akan menyesatkan kamu dari jalan Allah. Sesungguhnya orang-orang yang sesat darin jalan Allah akan mendapat azab yang berat, karena mereka melupakan hari perhitungan. (QS. Sad : 26).

Maka dari itu, para pemimpin harus memahami hakikat kepemimpinan itu sendiri. Menurut Abdul Mustaqim yang dikutip oleh Nur Efendi, prinsip kepemimpinan dalam islam terdapat 5 hal, yaitu:

1) Tanggung jawab, bukan keistimewaan

2) Pengorbanan, bukan fasilitas

3) Kerja keras, bukan santai

4) Kewenangan melayani, bukan sewenang-wenang

5) Keteladanan dan kepeloporan, bukan pengekor (Efendi, 2015)

Lima poin di atas harus tertanam dalam diri seorang pemimpin.

Karena hal ini menjadi kunci utama agar seorang pemimpin dapat berperilaku layaknya seorang pemimpin sejati. Karena seorang pemimpin yang sejati bukan hanya berorientasi dalam duniawi semata, namun juga dalam hal akhirat pula. Dengan demikian kepemimpinan yang dijalankan dapat berjalan dengan efektif dan pastinya mendapat berkah dari Allah swt.

\section{SIMPULAN}

Nilai dasar kepemimpinan pendidikan Islam adalah tolok ukur yang mendasari perilaku seorang pemimpin dalam melaksanakan kepemimpinan secara Islami. Kriteria nilai dasar kepemimpinan pendidikan Islam berpijak kepada ajaran agama Islam, baik yang tercantum di dalam kalam Allah (Al-Qur'an) atau pun hadits, serta dengan meneladani perilaku Rasulullah saw. Nilai dasar kepemimpinan pendidikan Islam dapat berpijak dalam wahyu agama Islam, baik yang tercantum pada Al-Qur'an dan hadits, serta meneladani perilaku Rasulullah saw., dimana nilai dasar tersebut meliputi: (1) cerdas atau fathonah, (2) jujur atau shidiq, (3) visioner, (4) inisiatif, (5) ikhlas berkorban, (6) bertanggung jawab atau amanah, (7) percaya diri, (8) berpikir positif, (9) responsif, (10) empati, (11) inovatif, (12) toleran, (13) keteladanan, (14) disiplin, dan (15) terbuka dan komunikatif.

Moralitas kepemimpinan pendidikan Islam merupakan perbuatan seorang pemimpin yang dianggap baik dan benar, dari sisi agama mencerminkan akhlakul karimah 
dan dari sisi sosial mencerminkan tindakan yang beradab. moralitas kepemimpinan pendidikan Islam berorientasi pada dunia dan akhirat sekaligus. Tidak hanya berorientasi pada dunia saja atau akhirat saja. Terdapat beberapa kriteria moralitas kepemimpinan pendidikan Islam, yaitu: (1) hati yang melayani, (2) kepala yang melayani, dan (3) tangan yang melayani.

\section{DAFTAR PUSTAKA}

Anam, C. (2017). Pengaruh kepemimpinan islam dan motivasi kerja islam terhadap kinerja karyawan. Istithmar Journal, 1(1), 11-29. https://doi.org/10.30762/itr.v1i1.936.

Burhanuddin. (2019). Kepemimpinan pendidikan Islam. AL-QALAM Jurnal Kajian Islam \& Pendidikan, 11(1), 1-6. https://doi.org/10.47435/al-qalam.v1i1.44.

Djihadah, N. (2020). Kecerdasan emosional dan kepemimpinan kepala madrasah dalam aplikasi Penguatan Pendidikan Karakter (PPK) di madrasah. Jurnal Pendidikan Madrasah, 5(1), 1-10. https://doi.org/10.14421/jpm.2020.51-01.

Efendi, N. (2015). Islamic educational leadership, Cet. I. Yogyakarta: Kalimedia.

Hemphill, J. K., \& Coons, A. E. (1957). Development of the leader behavior description questionnaire. In In R.M.Stogdill \& A.E.Coons (Eds), Leader behavior: Its Description and Measurement. Colombus: Bureau of Business Research, Ohio state University.

Hidayah, N. (2016). Kepemimpinan visioner kepala sekolah dalam meningkatkan mutu pendidikan, Cet. I. Yogyakarta: Ar-Ruzz Media.

House, R. J. (1976). A theory of charismatic leadership. In J. G Hunt and L. L. Larson (Eds), Leadership: The cutting edge. Carbondale: Southern Illinois University Press.

Ivancevich. (2008). Human resources management. Singapore: McGraw-Hill International.

Khumaini, F., \& Wiranata, R. R. S. (2019). Kepemimpinan dalam pendidikan Islam. FAHIM: Jurnal Manajemen Pendidikan Islam, 1(2), 1-17.

Maimunah. (2017). Kepemimpinan dalam perspektif Islam dan dasar konseptualnya. Jurnal Al-Afkar, 5(1), 59-82. https://doi.org/10.28944/afkar.v5i1.133.

Noor, J. (2013). Penelitian ilmu manajemen (tinjauan filosofis dan praktis).Jakarta: Kencana.

Peramesti, N., \& Kusmana, D. (2018). Kepemimpinan ideal pada era generasi milenial. Jurnal Manajemen Pemerintahan, 10(1), 73-84. https://doi.org/10.33701/jt.v10i1.413.

Pertiwi, A. K., Cahyani, S. S. A., Diana, R. C., \& Gunawan, I. (2017). Kepemimpinan berbasis nilai dan etika : suatu kajian interaksi simbolik kyai dan santri. Seminar Nasional Pendidikan - Fakultas Ilmu Pendidikan Universitas Negeri Malang, 1-9. Retrieved from http://ap.fip.um.ac.id/wp-content/uploads/2017/12/Adhe-Kusuma-PertiwiSinta-Septia-Anggra-Cahyani.pdf

Qodratillah, M. T. (2011). Kamus bahasa indonesia untuk pelajar. Jakarta: Badan Pengembangan dan Pembinaan Bahasa.

Rivai, V., Bachtiar, \& Amar, B. R. (2014). Pemimpin dan kepemimpinan dalam organisasi. Jakarta: Raja Grafindo Persada.

Rosyadi, K. (2004). Pendidikan profetik, Cet. I. Pustaka Pelajar.

Rusnadi, \& Hafidhah. (2019). Nilai dasar dan moralitas kepemimpinan pendidikan Islam. Jurnal Pendidikan Agama Islam, XVI(2), 223-244. https://doi.org/10.14421/jpai.2019.162-06. 
Shulhan, M. (2004). Administrasi pendidikan, Cet. I. Surabaya: Bina Ilmu.

Susanti, S. S. (2019). Moralitas kepemimpinan pendidikan berlandaskan agama, filsafat, psikologi, dan sosiologi. AS-SALAM Jurnal Ilmiah Ilmu-Ilmu Keislaman, II(3), 317376. http://journal.stai-yamisa.ac.id/index.php/assalam/article/view/30.

Syadzili, M. F. R. (2018). Model kepemimpinan dan pengembangan potensi pemimpin pendidikan Islam. Jurnal Cendekia, 4(2), 127-136. https://doi.org/10.37348/cendekia.v4i2.54.

Syam, A. R. (2017). Konsep kepemimpinan bermutu dalam pendidikan Islam. At-Ta'dib, 12(2), 49-69. https://doi.org/x.doi.org/10.21111/at-tadib.v12i2.1214.

Usman, H. (2014). Manajemen teori, praktik, dan riset pendidikan (4th ed.). Jakarta: Bumi Aksara.

Wahab, J. (2020). Nilai moralitas kepemimpinan pendidikan Islam. Jurnal Inspirasi Pendidikan, 9(1), 59-67. https://doi.org/10.24252/ip.v9i1.14124.

Yulk, G. (2010). Leadership in organization. Singapore: Prentice Hall International. 